\title{
The End of Progress on Earth
}

\section{Solveig Daugaard}

There are several analogies between innovations in communication technology and innovations in transportation technology in early media theory. This is no surprise since means of transportation and communication in the history of civilization has been completely entangled. In the chapter "Roads and Paper Routes" of Understanding Media (1964) Marshall McLuhan recounts how the Roman Empire triumphed over the Greek city states and village communities due to a convergence of innovations in transportation technology: the establishing of roads trafficked by horse carriages - and in communication media: the development of written, paper borne messages that could travel over much larger distances than before via the roads, that all lead, as we know, to Rome.

In terms of their conceptual history, the two things are tied even closer, since the term communication has been used in connection with roads, rivers and canals, long before becoming a term for information traffic. In the above mentioned chapter, McLuhan writes: 
In this book, we are concerned with all forms of transport of goods and information, both as metaphor and exchange. Each form of transport not only carries, but translates and transforms, the sender, the receiver, and the message. ${ }^{1}$

In McLuhan's conception, means of transport simply are media as he considers all technologies as media, or "extensions of man" - that is extensions of "our physical and nervous systems to increase power and speed." 2 Due to the increase of speed that came with road transport and paper messages, new communities were formed and new power structures were established that changed the entire ecology of civilization.

Quite a few years before McLuhan and his associates started working on media theory the American poet Gertrude Stein was going down a somewhat similar road. In her reflective, art critical essay Picasso (1938), about the work of her most famous painter friend, she writes:

the composition of each epoch depends upon the way the frequented roads are frequented, people remain the same, the way their roads are frequented is what changes from one century to another and it is that that makes the composition that is before the eyes of every one of that generation and it is that that makes the composition that a creator creates. ${ }^{3}$

In the following, I want to investigate how Stein's ideas of transport, composition and creation were shaped by her concrete experiences with the automobile and the airplane, the two major transport innovations of her time, both of which became significant metaphors in the conceptualization of her poetics as it was reformulated in the last decades of her life.

To unpack the quote just a little: "Composition" was Stein's preferred concept covering both the entire structure of daily life

1 Marshall McLuhan, Understanding Media. The Extensions of Man, London: Routledge 2001 (1964), p. 97-98.

2 Ibid., p. 98.

3 Gertrude Stein, Picasso. In: Writings 1932-1946, New York: Library of America 1998, p. 504. 
in an epoch, and the creative activities of the artist in this same epoch. It is more of a structural functionality than a category to describe a particular limited set of phenomena - and in this way, it somewhat resembles McLuhan's expansive concept of media. To Stein, the job of the artist was to articulate the changes in the composition of an epoch that were already there, but passed unnoticed for everyone else. As she proceeds in Picasso:

I very well remember at the beginning of the war being with Picasso on the boulevard Raspail when the first camouflaged truck passed. It was night, we had heard of camouflage but we had not yet seen it and Picasso amazed looked at it and then cried out, yes it is we who made it, that is cubism. ${ }^{4}$

Stein goes on to explain how in fact the composition of the first world war 1914-18 is "not one in which one man is in the center surrounded by a lot of other men," but a decentered composition "of which one corner was as important as another corner", in fact the composition of cubism.

Be that as it may, in 1915 Gertrude Stein and her partner Alice Toklas felt a need to flea for some time from the troubles of the war, cubist or not, and left their Paris studio for Palma de Mallorca, helped along by their friend the American painter William Cook and his wife, who had already lived on the island for some time. In spring 1917, after the battle of Verdun, they decided to go back to Paris. In The Autobiography of Alice B Toklas (1933), Stein's prank autobiography written in the voice of her companion, the narrator, Alice, accounts:

When it was all over [i.e. the battle of Verdun] we none of us wanted to stay in Mallorca any longer, we all wanted to go home. It was at this time that Cook and Gertrude Stein spent all their time talking about automobiles. They neither of them had driven but they were getting very interested. ${ }^{6}$

4 ibid.

5 Ibid., p. 504-505.

6 Gertrude Stein, The Autobiography of Alice B. Toklas. In: Writings 1903-1932, New York: Library of America 1998, p. 824. 
When Gertrude and Alice returned to Paris after a detour over Madrid, Cook had already realized his plans and was driving a Paris taxi to supplement his modest income as a painter. Back in a less troubled version of war-time Paris, Gertrude and Alice decided to get into the war and do their part. They managed to get a Ford car sent from Stein's cousin in America, and while they were waiting for it, William Cook taught Gertrude Stein how to drive his taxi. The two women soon started driving supplies to French hospitals around the country side for the organization The American Funds for French Wounded.

Stein and Toklas got rather attached to the car which they named "Auntie". More importantly, for my current purposes, driving also effectuated a change in Stein's experience of "the way the frequented roads were frequented" and thus suggested to her, that a new composition was in store. The automobile after this point became a crucial metaphor for Stein in her conceptualization of "the modern composition." In the lecture "Portraits and Repetition" written for her American lecture tour in 1934 she writes about the relation between modernity and movement: "the strange thing about the realization of existence is that like a train moving there is no real realization of it moving if it does not move against something and so that is what a generation does it shows that moving is existing." 7

According to Stein, this commonsense version of the principle of relativity became challenged in 20 th century America, where the importance of remembering previous generations in order to feel the progression of history had decreased:

[...] if the movement, that is any movement, is lively enough, perhaps it is possible to know that it is moving even if it is not moving against anything. And so in a way the American way has been not to need that generations are existing. ${ }^{8}$

7 Gertrude Stein, Lectures in America. In: Writings 1932-1946, New York: Library of America 1998, p. 287.

8 ibid. 
Here, Stein used the car to explain her idea of how this new condition was possible, where a new generation was not ahead of their own time, but moving so intensely in the middle of it that all context became irrelevant.

A motor goes inside of an automobile and the car goes. In short, this generation has conceived an intensity of movement so great that it has not to be seen against something else to be known, and therefore, this generation does not connect itself to anything, that is what makes this generation what it is and that is why it is American, $(\ldots) .9$

In Stein's conception in 1934 the ultimate sense of progress is closely connected to the car. The car is a symbol of absolute freedom from context, as it has no need for tracks (unlike the train), you can go wherever you please, with no need for a background to know that you are moving forward. With the car, the movement is intense enough in itself.

Stein's image of modernity is compelling because it is not the average traumatic one, where we see the relevance of tradition and anchoring dissolve, leaving the modern individual completely free floating and lost. Instead it is a self-contained position that is perfectly illustrated by technological progress in transportation. Yet, on the other hand, as is illustrated by the camouflage trucks of cubism, Stein is strikingly well in accordance with the close ties between inventions in media technology and warfare drawn by many media theorists, most prominently Friedrich Kittler. Here, it seems that, apart from being expressed by the innovative artists of a period, any new composition needs a war in order to be realized by the rest of the world. Stein makes this somewhat unpleasant aspect very explicit in Picasso:

It is an extraordinary thing but it is true, wars are only a means of publishing the things already accomplished, a change, a complete change, has come about, people no longer think as they were thinking, but no one knows it, no one recognizes it, no one knows it except the

9 Ibid., p. 287-288. 
creators. $(\ldots)$ the war is only something which forces everybody to recognize it. ${ }^{10}$

So, after the end of the war that had ostensibly publicized the composition already expressed in art and literature, Stein found that the time was finally ripe for publishing her own work. In 1920, she started intense preparations for getting out the first major collection of her writing. As usually in Stein's publication history, getting a book out proved somewhat difficult, but in 1922 Geography and Plays, containing an extensive selection of her work written between 1910 and 1920, was finally out. The book's title introduces into Stein's published vocabulary two new categories of writing within her system of genres, both of which are essentially spatial: the crucial notion of the play and the central concept of "Geography".

As has been well covered in the reception, Gertrude Stein's plays are readily recognizable as spatial due to their characteristic non-narrative and non-sequential construction. ${ }^{11}$ As Stein herself put it, "anything that was not a story could be a play" designating her own plays as "landscapes" rather than stories. ${ }^{12}$ Moreover, spatiality is a defining characteristic of the genre: all written plays are texts that have inherent in them a potential realization in the concrete, physical space of the stage. But in fact, it is the other half of the books' title, the - in a literary context - more enigmatic concept of "Geography" that connects most directly to Stein's experiences with driving through the open French landscape. In Stein's writing, geography is “never simply about location, scenery and the space of the earth, though it includes these" ${ }^{13}$ but is equally concerned with the spaces of writing, with spatiality as a principle for composition. Geography, in Stein's poetics is concerned with the arrangement of words

10 Gertrude Stein, Picasso. In Writings 1932-1946, New York: Library of America 1998, p. 518.

11 See for example Elinor Fuchs The Death of Character, 1996 and Bonnie Marranca "Presence of Mind" in Ecologies of Theater, 1996.

12 In her lecture "Plays" from Lectures in America. Quoted from: Writings 1932-1946, New York: Library of America 1998, p. 261.

13 Ulla E. Dydo and Gertrude Stein, A Stein Reader, Evanston: Northwestern University Press 1993, p. 467. 
in compositional space not tied to the stage, but to the written page.

Stein explored the concept in briefer compositions like "Geography"14 from 1923, where water, weather and waves become dominant free-floating elements in a punning flow of words that abandon sequence on a purely linguistic level, as well as in several other works written up through the 1920s. But it was not until years later, when she had traveled to America on her 1934 lecture tour and had her first experience with flying, that her concept of geography became fully unfolded.

Stein went back to America as she had left it, by steam ship, but well over the pond she became acquainted with the dawning aviation industry, as she was invited to attend the Chicago premiere in November 1934 of her success opera Four Saints in Three Acts ${ }^{15}$ only a few weeks after her ship had reached New York. Stein was absolutely terrified of heights and only very reluctantly led herself persuade to take the trip, on the condition that she could bring both Toklas and their friend Carl Van Vechten to hold her hand. As it turned out, she was absolutely thrilled by the experience.

After returning from America Stein wrote The Geographical History of America or The Relation of Human Nature to the Human Mind (1936), in which she developed her concept of "geography" to become a whole mode of writing that extended beyond her spatial sense of composing for the theatre and beyond the traditionally framed prose text of "Geography". In this peculiar and complex work of literary meditation Stein performs her most elaborate investigation and manipulation of the formalized, material components that organize written texts spatially as well as sequentially by sophisticating her

\footnotetext{
14 Like so many other compositions by Stein "Geography" remained unpublished in her lifetime, and was first printed in Painted Lace, and Other Pieces, the fifth volume of the Yale edition of the Unpublished Writings of Gertrude Stein in 1955. Reprinted in A Stein Reader in 1993.

15 The opera with music composed by Virgil Thomson had premiered in Hartford, Connecticut in February 1934 and then ran for over two months on Broadway, becoming the longest-running opera on Broadway ever at this time. Stein's libretto was first printed in extracts in transition 16/17 in 1929 and in its entirety in Operas and Plays in 1932.
} 
concept of "geography." It becomes a functional, broad, and spatially conceived perspective on composition that challenges the sequential progress of linear narrative. In her history of geography, Stein makes a new combination in writing of time and space that is derived from her experience of seeing America from above. The text promises to be a description of "how the country looked as we passed over it" and "of how the land the American land the land in America looks and is flat is and looks flat". ${ }^{16}$

These promised descriptions of the country are never realized in further detail in the highly playful, punning text, that appears compelling, crystal clear and easy to follow when one is reading it - and yet completely impossible to paraphrase whenever one stops reading. But a new freedom clearly comes into Stein's practice of geography in this work. Evidently, this happened in direct connection with her experience of air travel, because flying introduced to her a fundamentally different relation between time and space than the one she had known from driving. In a car, Stein suggests, you see the landscape changing swiftly as you go by, whereas when you are on a plane the landscape appears complete at every moment: what you see almost does not change from one moment to the next. This is something more radical than the plane's independency of designated roads and of the entire flat surface of the earth that it makes effortlessly perceivable for its passengers. In Stein's experience, what is so radical about flying is that her experience of progression in the journey is so small that it becomes almost non-existent. This fundamentally affects her mind as traveler and artist and in the course of The Geographical History it is continuously transferred from the space of the earth to the space of the writing and back again, as she writes in Chapter II: "This chapter is to be all about when words (...) look like that. Like that. Like it did when I looked at it, there there where I saw it. Beneath me when I was above it." ${ }_{17}$

16 Gertrude Stein, The Geographical History of America or The Relation of Human Nature to the Human Mind. In: Writings 1932-1946, New York: Library of America 1998, p.

373 and p. 383 .

17 Ibid., p. 380. 
The Geographical History of America proceeds through chains of literary genre miniatures, indicated by headlines such as "Autobiography number one", "Autobiography one again", "Detective Story number VII", "A little play", "Play number X", and constantly shifts and shuffles loose running structural units like "Chapter 2", "Part III", "Part fifteen", "Act I Scene I", "Number six and seven", "Example Four" and "Interlude I", explicitly defying the rules of sequence to create a simultaneous spatial murmur of elements co-existing on the space of the pages but refusing to organize themselves temporally. In another one of the countless occurrences of a "Chapter II" this principle is confessed: "There is no reason why chapters should succeed each other since nothing succeeds another, not now any more. In the old novels yes, but not now anymore (...) Everybody knows just how nothing succeeds anything." 18

Just like Stein's numbering of the different structural units seems to fall completely off the chart, there are also very few text-intrinsic indicators supporting the frequent changes in genre labels. The same style of punning prose progressing by its own mediational logic of chatty yet serious literary thinking runs through the whole work. Yet, the text insists strongly on the importance of the genres and units, and half through, not in a Chapter II but in a Part II, makes yet another chain of bold claims about genre that seems to immediately disarm each other:

The whole book now is going to be a detective story of how to write.

A play of the relation between the human nature and the human mind.

And a poem of how to begin again.

A description of how the earth looks as you look at it which is perhaps a play if it can be done in a day and is perhaps a detective story if it can be found out. ${ }^{19}$

18 Ibid., p. 390.

19 Ibid, 409 
Yet, clearly, all the generic labels are equally true, as Stein in the genre-miniatures of Geographical History of America Stein is demonstrating the functionality of genres as a spatial perspective that does not follow from the inherent characteristics of a text, but is something that is applied to a text, and when it is, changes that text radically. That "this whole book" is "a play if it can be done in a day" and "a detective story if it can be found out" suggests two completely different approaches to reading the same text. This spatial take on literary genre has a similar implication as a theatrical translation of a written play into a three-dimensional theatre space, even if it, in terms of medium, stays on the flat surface of the paper.

With flying, Stein's perspective on space and time was radically transformed: "One must not forget" she concludes in $P i$ casso "that the earth seen from an airplane is more splendid than the earth seen from an automobile". And continues:

The automobile is the end of progress on earth, it goes quicker but essentially the landscapes seen from an automobile are the same as the landscapes seen from a carriage, a train, a wagon, or in walking. But the earth seen from an airplane is something else. And so the twentieth century is not the same as the nineteenth century.

She goes on to identify in the American landscape she overflew on her first plane ride from New York to Chicago "all the lines of cubism made at a time when no painter had ever gone up in an airplane". ${ }^{20}$

Clearly, the experience of flying retrospectively influenced Stein's understanding of painterly cubism, but even more it influenced how she conceived and composed her own writing, as is demonstrated by the geographical concept of composition that she develops in The Geographical History and revisits in late key works like Ida. A novel (1941) and Four in America (1947).

20 Gertrude Stein, Picasso. In Writings 1932-1946, New York: Library of America 1998, p. 532-533. 